\title{
EDENIC LANGUAGE SEBAGAI BAHASA IBRANl: Ibu Bagi Seluruh Bahasa Di Dunia
}

\author{
Wahyoe Rita Wulandari \\ Biblical Hebrew Research Center - STT Ekumene, Jakarta \\ Lecturer in Biblical Studies - Israel Bible Center \\ Email: rwahyu@israelbiblecenter.com
}

Submited: 14 January 2021 Revision: 26 April 2021 Published: 28 May 2021

\begin{abstract}
Edenics is the Semitic mother tongue that was scrambled into 70 languages on about 3,784 years ago, after the episode of the Tower of Babel. According to the theory of Dr. Isaac E. Mozeson, every human language today shares elements of Biblical Hebrew. By the research work of Mozeson regarding "Edenic Language" in relation to Hebrew which influenced many languages of the world. He calls "Edenics" this "proto-human language" because of its connection with the Garden of Eden, where the first human were created. Therefore, Edenics is the originally Biblical Hebrew language.
\end{abstract}

Keywords: language, edenic, hebrew

\begin{abstract}
Abstrak
Edenics adalah bahasa ibu Semit yang terurai ke dalam 70 bahasa pada sekitar 3.784 tahun yang lalu, pada peristiwa Menara Babel. Menurut teori Dr. Isaac E. Mozeson setiap bahasa saat ini memiliki elemen yang sama dalam bahasa Ibrani Alkitabiah.

Melalui penelitian Mozeson tentang "Bahasa Edenic" dalam kaitannya dengan bahasa Ibrani yang mempengaruhi banyak bahasa di dunia. Dia menyebut "Edenics" ini "proto-human language" karena hubungannya dengan Taman Eden, tempat dimana manusia pertama diciptakan dan di tempatkan di sana. Maka Edenics adalah mula dari bahasa Ibrani Alkitabiah.
\end{abstract}

Kata Kunci: bahasa, edenik, ibrani

\section{PENDAHULUAN}

Pada mulanya hanya terdapat satu bahasa saja. Namun kemunia bahasa manusia dibumi, oleh kuasa Allah telah dijadikan menjadi berbagai macam bahasa sejak peristiwa pengacauan menara Babel. Maka, pastilah ada yang menjadi "ibu" bagi semua bahasa-bahasa ini. Permulaannya, tentulah bahasa yang digunakan manusia di Taman Eden - dan bahasa ini disebut dengan "Edenic" oleh oleh seorang linguist Israel, Isaac $E$. Mozeson. Edenic dipergunakan manusia setelah masa pengusirannya dari taman 
Eden, ${ }^{1}$ dan terus dipergunakan pada era Nuh dan putera-puteranya, hingga peristiwa di Babel padad zaman Nimrod. Bahasa dan kata melahirkan peradaban, pada mulanya di dunia ini hanya memiliki satu bahasa dan satu logatnya. Alkitab menuliskan:

*Kejadian 11:1

LAI TB, Adapun seluruh bumi, satu bahasanya dan satu logatnya.

$\mathrm{KJV}$, And the whole earth was of one language, and of one speech.

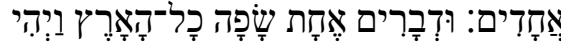

Translit interlinear, VAYEHI \{dan terjadi\} KHOL-HA'ARETS \{pada seluruh bumi\} SAFAH \{bahasa\} 'EKHAT fyang satu\} UDEVARIM \{dan perkataan-perkataan\} 'AKHADIM \{yang satu\}. ${ }^{2}$

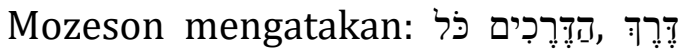
בָָָּ - KOL HADER. EKHIM DEREKH BAVEL, all roads led from Babel. Pengacauan bahasa manusia - Edenic dari satu bahasa menjadi macam-macam bahasa bermula dari Babel ini. Para creationist dan evolunionist dalam hal ini bersepakat bahwa peristiwa pengacauan

${ }^{1}$ Baca Eric C. Loy. "Savage Garden: Edenic Motif and the Paradox of Civilization in Child of God." The Cormac McCarthy Journal 12 (2014): 5568.

http://www.jstor.org/stable/10.5325/cormmccaj .12 .55 .

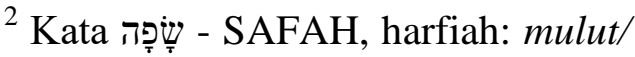
bibir, dalam konteks tertentu artinya: bahasa. Ada juga kata לִ LASHON, harfiah: lidah, dalam konteks tertentu artinya: bahasa. bahasa di Babel, menjadikan adanya bahasa-bahasa baru dari masing-masing bangsa-bangsa. Bahwa Allah sendirilah inisiator dari pengacauan bahasa oleh karena pemberontakan di Babel itu. ${ }^{3}$

Metode penulisan yang digunakan adalah metode kualitatif deskriptif dengan jenis gramatika dan semantik bahasa. Jenis analisis gramatika adalah menganalisa struktur bahasa dari teks Ibrani dan semantik bahasa ini adalah mengambil makna dari hasil analisa gramatika teks Ibrani.

\section{HASIL DAN PEMBAHASAN}

\section{Edenics - Mula Dari Bahasa Ibrani}

Alkitabiah

Mozeson membuahkan karya penelitiannya yang ia sebut dengan "Edenic Language" dalam kaitannya dengan bahasa Ibrani yang mempengaruhi banyak bahasa-bahasa di dunia.. ${ }^{4}$ Dia menyebut "Edenics" adalah "proto-human language" ini karena hubungannya dengan Taman Eden, dimana manusia pertama diciptakan dan

\footnotetext{
${ }^{3}$ Bodie Hodge. (2013) Tower of Babel, The Cultural History of Our Ancestors. Green Forest: Master Books. 65

${ }^{4}$ Band. reportase dari Dr. Rivkah Lambert Adler. Reff. https://www.breakingisraelnews.com/ 138823/biblical-hebrew-mother-languages-beforeafter-tower-babel/ (diakses 10 Feb. 2021)
} 
ditempatkan di situ. Maka "Edenics" adalah mula dari bahasa Ibrani Alkitabiah. ${ }^{5}$

Bahasa Ibrani, selalu memiliki akar kata (SORESH) yang terdiri dari dua atau tiga konsonan Ibrani. Mari kita perhatikan secara sederhana bahwa dua dan tiga akar kata konsonan dari bahasa Ibrani itu menyebar pada sebagian besar bahasabahasa di dunia, sehingga itu akan membuat penerjemahan kembali katakata itu ke dalam bahasa Ibrani jauh lebih mudah. ${ }^{6}$

Bahasa Ibrani adalah salah satu kontributor terbesar untuk kosakata bahasa Inggris Modern. Dr. Mozeson mencatat secara khusus lebih dari 22.000 "kebetulan" dalam etimologi. Di sini, Dr. Mozeson telah menelitinya dari sisi fonetik dan kajian dari dua atau tiga konsonan akar kata Ibrani. Ini menjadi salah satu bukti yang jelas dari firman Tuhan yang memang telah menuliskan: "Adapun seluruh bumi, satu bahasanya dan satu logatnya" (Kej 11:1). Inilah yang mendasari semua bahasa itu berasal dari dari Satu Bahasa Asli, yaitu bahasa Ibrani!

5 Reff. Edenics DVD on Edenic (Biblical Hebrew) as the original, pre-Babel human language program. http://www.edenics.org/

${ }^{6}$ Elder Conrad Jarrell. (2018) The Story in The Stars. Morrisville: Lulu.com. 20-21.
Banyak kata telah berubah, namun semuanya dapat ditelaah dari mana kata tsb. berasal. ${ }^{7}$

Pada bulan Mei 2020, mula pertama saya berkorespondensi dengan Dr. Mozeson, dan setelah mempelajari temuannya dan pemikirannya yang luar biasa ini pada pre-Babel human language program yang diciptakannya. Dr. Mozeson menyatakan bahwa Edenics adalah "Semitic mother tongue" yang "diurai menjadi 70 bahasa" pada 3.784 tahun yang lalu, setelah peristiwa Menara Babel. Menurut teorinya, setiap bahasa manusia saat ini memiliki unsur-unsur bahasa Ibrani. Dan Edenics adalah bahasa praYahudi. ${ }^{8}$

Nama-nama orang-orang Ibrani selalu memiliki arti. Mulanya, tentu saja dari seseorang yang berasal dari GAN-BE'EDEN - taman di Eden. Demikian juga nama Nuh - jo - NOAKH - yang memiliki arti sesuai namanya: penghiburan (rest). Nama-nama orang Ibrani sejak Adam hingga hari ini, orang-

${ }^{7}$ Isaac E. Mozeson. (2001) The Word: The Dictionary Reveals the Hebrew Sounce of English. New York: S.P.I. Books. 1.

${ }^{8}$ Saya harus berterimakasih pada Dr. Isaac E. Mozeson untuk beberapa sesi diskusi khusus melalui email tentang Edenic Language. Band. 
orang Yahudi senantiasa menganggap penting makna dari nama-nama mereka.

\section{Nama Adam - Generasi Pertama Edenic}

Contoh kata yang dapat menjelaskan riset dari Dr Mozeson tentang "Edenics." Dengan mengambil kata yang memang berasal dari Eden. Yaitu nama 'ADAM - artinya: manusia:

\section{* Kejadian 2:7}

LAI TB, ketika itulah TUHAN Allah membentuk manusia itu (HA'ADAM) dari debu tanah (HA'ADAMAH) dan menghembuskan nafas hidup ke dalam hidungnya; demikianlah manusia itu menjadi makhluk yang hidup.

$\mathrm{KJV}$, And the LORD God formed man of the dust of the ground, and breathed into his nostrils the breath of life; and man became a living soul.

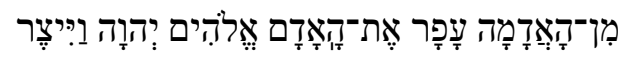

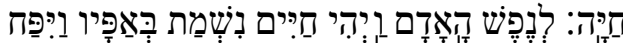

Translit interlinear, VAYITSER \{dan membentuk\} YEHOVAH \{baca: 'Adonay, TUHAN\} 'ELOHIM \{Allah\} 'ET- \{pada\} HA'ADAM \{manusia\} 'AFAR \{debu\} MIN\{dari\} HA'ADAMAH \{tanah\} VAYIPAKH \{dan Dia menghembuskan\} BE'APAV \{ke dalam hidungnya\} NISH'MAT \{nafas\} KHAYIM \{hidup\} VAYHI \{dan ia menjadi\} HA'ADAM \{manusia itu LENEFESH \{sebagai jiwa\} KHAYAH \{yang hidup\}

Kata ℸָָָָ - 'ADAM - manusia terhubung dengan kata אִדָ - 'ADAMAH, artinya: tanah. Satu media dari mana 'ADAM itu dibentuk/ diciptakan. Kata
'ADAM ADAM, Ibrani: [דָ - 'ADAM manusia - terhubung dengan kata kerja yang sama אָָ - 'ADAM bermakna "memerah/ menjadi merah." Terhubung juga dengan nomina - - DAM, artinya “darah." Kata - sempurna antara fisik dan spiritual - DAM - "darah." Itu menunjukkan sisi fisik manusia. Ada juga sisi spiritual: $\mathrm{x}$ - ALEF אָָלָ - yang terhubung dengan "Nama Allah" atau "karakter Allah" - אמלדים 'ELOHIM - ada di dalam diri manusia. ${ }^{9}$

Hewan/ binatang dan tumbuhan mereka memiliki kehidupan, namun mereka tidak memiliki sisi spiritual, kehidupan mereka tidak terkoneksi secara hubungan yang erat dengan Allah Pencipta. Jika ada orang yang membuang kebutuhan sisi fisik-nya. Dan dia hanya mengutamakan Allah, mementingkan

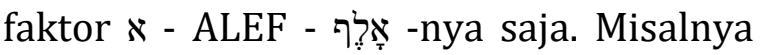
ada seorang yang meninggalkan seluruh kesenangan duniawi, bertapa di gunung. Menyendiri, menjauhi perkumpulan dengan teman-temannya, keluarganya. Tidak menikah, tidak bersosialisasi, sama sekali terlepas dari hal-hal kebutuhan sisi

\footnotetext{
9 Rita Wahyu. (2019) Eksegesis Peshat Kitab Kejadian-Kitab Genealogi, Parashat Bereshit 1:1-6:8. Jakarta: STT Ekumene. 223
} 
fisiknya. Apakah dia akan hidup berbahagia? Tidak!

Dalam kehidupan manusia haruslah memenuhi 3 aksara seperti pada kata אָָָָ - 'ADAM itu. Ada 2 elemen, pada kata itu, yaitu sisi spiritual - ALEF unsur 'ELOHIM (manusia adalah gambar dan rupa Allah); ${ }^{10}$ ada sisi ragawi/ fisikal - - ד̦ - DAM, itulah komposisi yang sempurna. Mari kita mengkaji nama-nama lainnya dari Generasi manusia mula-mula yang berasal dari Eden.

\section{Nama Hawa - Generasi Pertama Edenic}

Adam menamai istrinya: Hawa (Ibr: ח - KHAVAH), dasar filosofis pemberian nama itu karena: dia adalah ibu dari semua yang hidup (Ibr: 1 - KHAY). Bentuk penulisan - KHAVAH terkoneksi dengan חָיזיה - KHAYAH, artinya: makhluk hidup/ bernyawa. Kata Ibrani: ח - KHAY atau חיים - KHAYIM mengkomunikasikan gagasan "hidup" dalam bahasa Ibrani. Oleh karena itu, janji Allah dalam Kejadian 3:15 diresponi Adam dengan iman, yaitu memanggil istrinya dengan nama: חְַּּ - KHAVAH, karena dari dia akan

\footnotetext{
${ }^{10}$ Rita Wahyu. (2019) Eksegesis Peshat Kitab Kejadian-Kitab Genealogi, Parashat Bereshit 1:1-6:8, 149.
}

lahir seluruh umat manusia - חָָּ - KOL KHAY - yang akan memenuhi bumi.

${ }^{*}$ Kejadian 3:20

LAI TB, Manusia itu memberi nama Hawa (KHAVAH) kepada isterinya, sebab dialah yang menjadi ibu semua yang hidup (KHAY).

$\mathrm{KJV}$, And Adam called his wife's name Eve (KHAVAH); because she was the mother of all living (KHAY).

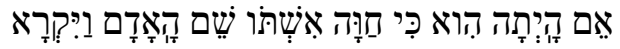

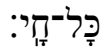

Translit interlinear, VAYIQ'RA \{dan dia memanggil/ memberi nama\} HA'ADAM \{manusia itu\} SHEM \{nama\} 'ISH'TO \{kepada istrinya\} KHAVAH \{hawa, harf: sesuatu yang hidup\} KI \{sebab $\mathrm{HI}$ \{darinya\} HAY'TAH \{telah menjadi\} 'EM \{ibu dari\} KOL-KHAY \{semua yang hidup\}

Bandingkan dengan terjemahan Septuaginta untuk Kej. 3:20, tentang nama dari perempuan itu:

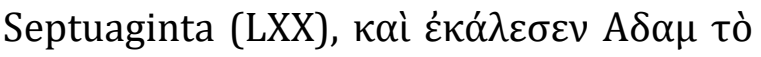

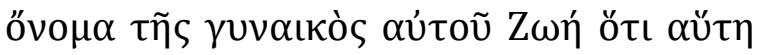

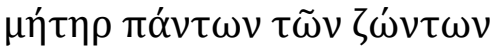

Translit interlinear, KAI \{dan\} EKALESEN \{dia memanggil\} ADAM \{manusia/ adam\} TO ONOMA \{nama\} GUNAIKOS \{istri\} AUTOU \{-nya\} ZốE \{hidup\} HOTI \{bahwa\} AUTÊ \{dia\} MÊTÊR \{ibu\} PANTÔN \{bagi semua\} TÔN ZÔNTÔN \{yang hidup\}

Terjemahan Septuaginta Yunani menerjemahkan kata Ibr: חְְִּ - KHAVAH itu secara harfiah dengan kata Yunani:

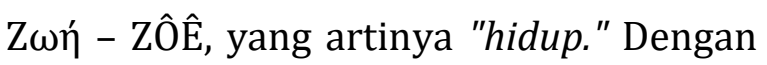
demikian terlihat jelas bahwa nama - 
KHAVAH mengandung makna חדיזה KHAYAH yang berhubungan dengan makhluk hidup. Ketika nama ח KHAVAH diterjemahkan, dalam bahasa lain, walau itu dalam bahasa Alkitabiah lainnya, yaitu bahasa Yunani, nilai fonetik terhadap maknanya telah terhapus.

\section{Nama Kain - Generasi Kedua Edenic}

Kain adalah anak pertama yang lahir di bumi dari pasangan manusia pertama, Adam dan Hawa. Kain, Ibrani בין - QAYIN, artinya: milik, possession. Nama "QAYIN" ini berkaitan dengan ucapan kegembiraan Hawa saat dia mendapatkan anak laki-

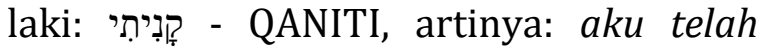
mendapat/ memperoleh, Verb Qal Perfect $1^{\text {st }}$ Com. Sing.

\section{* Kejadian 4:1}

LAI TB, Kemudian manusia itu bersetubuh dengan Hawa, isterinya, dan mengandunglah perempuan itu, lalu melahirkan Kain; maka kata perempuan itu: "Aku telah mendapat seorang anak laki-laki dengan pertolongan TUHAN." $\mathrm{KJV}$, And Adam knew Eve his wife; and she conceived, and bare Cain, and said, I have gotten a man from the LORD.

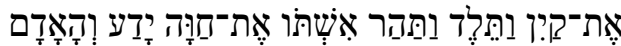

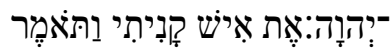

Translit interlinear, VEHA'ADAM \{dan manusia itu\} YADA \{ia telah mengenal, majas eufemisme "bersetubuh" $\}$ 'ET\{kepada\} KHAVAH hawa\} 'ISH'TO \{istrinya $\}$ VATAHAR \{dan dia mengandung $\}$ VATELED \{dan dia melahirkan\} 'ET- \{pada\} QAYIN \{kain\}
VATOMER \{dan dia berkata\} QANITI \{aku telah mendapat/ memperoleh, Verb Qal Perfect $1^{\text {st }}$ Com. Sing.\} 'ISH \{seorang laki-laki\} 'ET- \{dari\} YEHOVAH (dibaca 'Adonay, TUHAN).

Hawa mengatakan, "Aku telah mendapatkan seorang laki-laki dengan pertolongan TUHAN" (Kejadian 4:1), sebagai pengucapan syukur kepada Allah, sehingga mereka masih diberi kemampuan dan kesempatan menghasilkan keturunan, sebab mereka yang telah jatuh ke dalam dosa. Pada saat ini dimulailah pengalaman nyeri bersalin pada segenap perempuan keturunan Adam (Kejadian 3:16). Hawa mensyukurinya walau dengan kesakitan dalam melahirkan putera, namun pertolongan Allah membuatnya tetap hidup.

\section{Nama Habel - Generasi Kedua Edenic}

Habel, Ibrani: הֶֶ - 'HEVEL, putra kedua Adam dan Hawa, dan adik dari Kain. Nama הֶֶ - 'HEVEL, artinya adalah: hembusan nafas, kesia-siaan. Ayat 2 memberi keterangan, Kain adalah petani/ penggarap tanah, sedangkan adiknya, Habel yang adalah gembala.

* Kejadian 4:2

LAI TB, Selanjutnya dilahirkannyalah Habel, adik Kain; dan Habel menjadi 
gembala kambing domba, Kain menjadi petani.

$\mathrm{KJV}$, And she again bare his brother Abel. And Abel was a keeper of sheep, but Cain was a tiller of the ground.

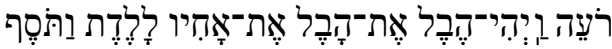

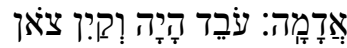

Translit interlinear, VATOSEF \{dan dia selanjutnya LALEDET \{melahirkan\} 'ET\{pada\} 'AKHIV \{saudara laki-lakinya\} 'ET\{pada\} HAVEL \{habel\} VAYEHI-HEVEL \{dan habel menjadi\} RO'EH sseorang gembala $\}$ TSON \{kambing/ domba\} VEQAYIN \{dan kain\} HAYAH \{dia menjadi\} 'OVED \{pekerja/ petani\} 'ADAMAH \{pada tanah\}

Habel tergolong seorang yang berumur pendek, bagaikan durasi udara yang dihirup kemudian dihembuskan, lalu hilang, demikianlah makna nama itu dalam bahasa Edenic yang menjadi muasal bahasa Ibrani.

\section{Bahasa Inggris - Hubungan Dengan Edenic - Ibrani}

Mozeson memperkirakan ada 20,000 lebih kata dalam bahasa Inggris berasal

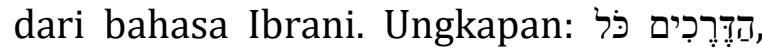

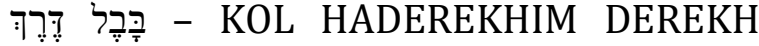
BAVEL, all roads led from Babel. Kata רִּרְ DEREKH, artinya, way, path, journey. Ini mirip dengan kata dalam bahasa Inggris "direct" dan kata dalam bahasa Jawa "nderek" yang berhubungan dengan makna itu.

Beberapa contoh kata-kata dalam bahasa Inggris di bawah ini, disajikan menurut penelitian Dr. Mozeson.

\section{Cover - KAFAR}

Kata bahasa Inggris "Cover" atau dalam bahasa Indonesia digunakan untuk menyebut "tas koper" (untuk berpergian). Asalnya dari bahasa Ibrani, yang artinya "penutup," perhatikan ayat ini:

\section{* Kejadian 6:14}

LAI TB, Buatlah bagimu sebuah bahtera dari kayu gofir; bahtera itu harus kaubuat berpetak-petak dan harus kaututup dengan pakal dari luar dan dari dalam. $\mathrm{KJV}$, Make thee an ark of gopher wood; rooms shalt thou make in the ark, and shalt pitch it within and without with pitch.

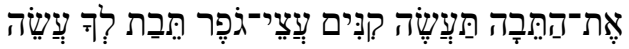


Translit interlinear, 'ASEH \{buatlah\} LEKHA $\{$ bagi-mu $\}$ TEVAT \{sebuah bahtera\} 'ATSEY-GOFER \{dari kayu gofir\} QINIM \{berpetak-petak\} TA'ASEH \{kamu harus membuat\} 'ET-HATEVAH \{pada bahtera itu\} VEKHAFAR'TA \{dan kamu akan menutup\} 'OTAH \{-nya\} MIBAYIT \{dari dalam\} UMIKHUTS \{dan dariluar\} BAKOFER \{dengan penutup\}.

Kata Ibrani kapparah (Ibrani: KAPORAH, (di dalam Alkitab menjadi gelar bagi Yesus Kristus sebagai "Juru Damai" (Propisiasi), berasal dari Verba 
כָּפ - KAFAR, Khaf-Fe-Resh, untuk menebus, untuk menutup. Kata כָּ KAFAR dalam bentuk participle adalah: - KOFER, artinya "menutupi (to cover/ covering)."

\section{Call - QOL}

Kata dalam bahasa Inggris "Call" (memanggil) berhubungan dengan kata dalam bahasa Ibrani קול - QOL, artinya : memanggil dengan suara, suara, panggilan. Perhatikan ayat ini:

*Yesaya 40:3

LAI TB, Ada suara (QOL) yang berseruseru: "Persiapkanlah di padang gurun jalan untuk TUHAN, luruskanlah di padang belantara jalan raya bagi Allah kita!

KJV, The voice (QOL) of him that crieth in the wilderness, Prepare ye the way of the LORD, make straight in the desert a highway for our God.

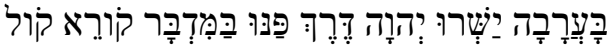

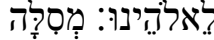

Translit interlinear, Q0L \{suara, panggilan dengan suara\} QORE' \{dia yang berseru\} BAMID'BAR \{di padang gurun\} PANU \{kalian persiapkanlah\} DEREKH \{jalan\} YEHOVAH \{dibaca: 'Adonay, TUHAN\} YASH'RU \{kalian luruskanlah\} BA'ARAVAH \{di padang belantara\} MESILAH \{jalan\} LELOHEINU \{bagi Allah kita\}.

\section{Antique - ATIQ}

Kata dalam bahasa Inggris "antique" (bahasa Indonesia: "antik") berhubungan dengan kata Ibrani - עַת - ATIQ. Perhatikan ayat ini:

*1 Tawarikh 4:22

LAI TB, lalu Yokim dan orang-orang Kozeba, lagi Yoas dan Saraf yang menguasai Moab dan kemudian pulang ke Betlehem; --riwayat-riwayat ini tua.

$\mathrm{KJV}$, And Jokim, and the men of Chozeba, and Joash, and Saraph, who had the dominion in Moab, and Jashubilehem. And these are ancient things.

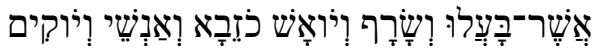

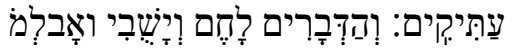

Translit interlinear, VEYOQIM \{dan yokim\} VE'ANSHEY \{dan orang-orang dari\} KHOZEVA \{kozeba\} VEYOASH \{juga yoas\} VESARAF \{dan saraf\} ASHER\{yang\} BAALU \{mereka menguasai\} LEMO'AV \{pada moab\} VEYASHUVI \{dan mereka kembali\} LAKHEM \{(pada) betlehem\} VEHAD'VARIM \{dan hal-hal/ riwayat-riwayat ini\} 'ATIQIM \{adalah halhal yang tua/ antik\}

Kota Yerusalem - YERUSHALAYIM disebut sebagai "kota

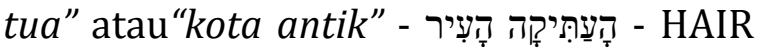
HA'ATIQAH dan "kota yang bertakhtakan

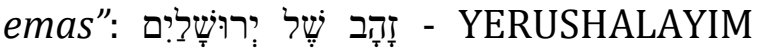
SHEL ZAHAV. 


\section{Earth - ERETS}

Kata dalam bahasa Inggris - אֶרץ 'ERETS, 'Alef-Resh-Tsade -A-R-TS adalah nomina berarti bumi, daratan. Kata ini digunakan 2.500 kali di dalam Tanakh Ibrani. Permutasi aksara-aksara tsb. membentuk kata dalam bahasa Inggris “EARTH.”

* Kejadian 14:19

LAI TB, Lalu ia memberkati Abram, katanya: "Diberkatilah kiranya Abram oleh Allah Yang Mahatinggi, Pencipta langit dan bumi (ERETS),

$\mathrm{KJV}$, And he blessed him, and said, Blessed be Abram of the most high God, possessor of heaven and EARTH (ERETS):

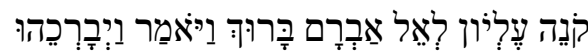

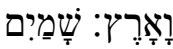

Translit interlinear, VAYEVARAKHEHU \{dan ia memberkati\} VAYOMAR \{dan dia berkata\} BARUKH \{diberkatilah\} 'AV'RAM \{Abram\} LE'EL \{oleh Allah\} 'EL'YON \{yang Mahatinggi\} QONEH \{yang Empunya\} SHAMAYIM \{langit\} VA'ARETS \{dan bumi\}

\section{Regular - REGEL}

Kata dalam bahasa Inggris "regular" yang berarti: biasa/ kebiasaan, berhubungan dengan kata Ibrani: רֶֶֶר REGEL - Resh-Gimel-Lamed -R-G-L, artinya: "kaki." Istilah itu muncul dari "kebiasaan" orang-orang Yahudi yang melakukan perjalanan ibadah dengan berjalan kaki ke Yerusalem untuk "naik haji"11 ke bukit Sion (memperingati hari raya di Yerusalem) secara rutin 3 kali dalam setahun (Kel. 23:14). Ziarah ini

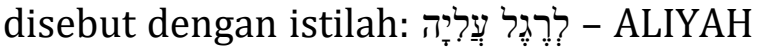
LEREGEL, harfiah: "ascent by foot, the foot-pilgrimage." Pengambilan kata "regel" yang kemudian berubah lafal menjadi "regular." Mengambil tradisi ibadah Yahudi.

* Keluaran 23:14

LAI TB, Tiga kali setahun haruslah engkau mengadakan (REGEL, harf: perjalanan dengan kaki) perayaan (KHAG) bagi$\mathrm{Ku}$.

$\mathrm{KJV}$, Three times thou shalt keep a feast unto me in the year.

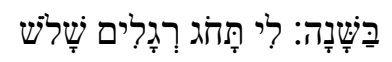

Translit interlinear, SHALOSH \{tiga kali\} REGALIM \{perjalanan dengan kaki - RG-L\} TAKHOG \{kamu harus merayakan, Verb Qal Imperfect $2^{\text {nd }}$ Mas. Sing.\} LI \{untuk-Ku\} BASHANAH \{dalam setahun\}

\section{School - Sekolah - HASKALAH}

Kata "skill" berhubungan dengan kata

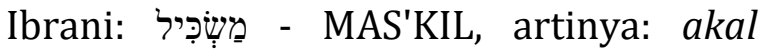
budi/ kemampuan (Mzm. 42:1, 45:1, 47:78, 89:1-2, 1 Sam. 18:5, Yes. 52:13). Katakata yang berhubungan dengan kata "MAS'KIL" ini adalah:

11 Kata Ibrani: חַ - KHAG, artinya: hari raya/ perayaan/ festival paralel dengan kata Arab "Hajj (الحجّ)." 


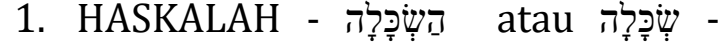
SEKALAH , artinya: pendidikan, pengetahuan, the Enlightenment movement.

2. MUS'KAL masuk akal, biasanya digunakan kepada suatu kesimpulan yang merujuk sesuatu setelah melalui kajian-kajian/ pertimbanganpertimbangan tertentu.

3. SEKEL - שָָָׁ - kecerdasan, otak, akal sehat, intelligence. Kata ini diserap

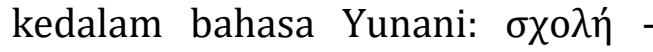
SKHOLÊ, atau $\sigma \chi 0 \lambda \alpha$ - SKHOLA, yang kemudian menjadi kata yang kita kenal sekarang School atau sekolah dalam bahasa Inggris dan bahasa Indonesia.

\section{Corona dan Edenics - Ibrani}

Kata Latin "Corona" (artinya: mahkota), yang oleh WHO dijadikan nama bagi virus yang menjadi pandemi dunia “COVID-19" (Corona Virus Disease 2019). Kata "Corona" itu berhubungan dengan kata Ibrani קהבון - QARAN, artinya: bersinar dan קְִּ -QEREN, artinya: tanduk.

Perhatikan ayat ini:

* Keluaran 34:29

LAI TB, Ketika Musa turun dari gunung Sinai -- kedua loh hukum Allah ada di tangan Musa ketika ia turun dari gunung itu -- tidaklah ia tahu, bahwa kulit mukanya bercahaya oleh karena ia telah berbicara dengan TUHAN.

$\mathrm{KJV}$, And it came to pass, when Moses came down from mount Sinai with the two tables of testimony in Moses' hand, when he came down from the mount, that Moses wist not that the skin of his face shone while he talked with him.

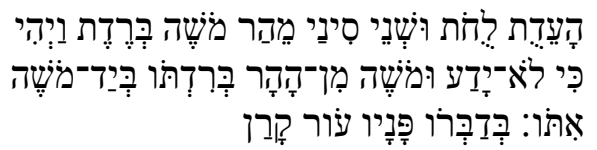

Translit interlinear, VAYEHI \{dan dia ada/ dan terjadi, Verb Qal Imperfect $3^{\text {rd }}$ Mas. Sing.\} BEREDET \{ketika dia turun, Verb Qal Infinitive Construct\} MOSHEH \{musa\} MEHAR \{dari gunung\} SINAY \{sinai\} USHENEY \{dengan dua dari\} LUKHOT \{loh-loh\} HA'EDUT \{perjanjian\} BEYADMOSHEH \{di tangan dari musa\} BERID'TO \{dan ketika dia turun\} MIN-HAHAR \{dari gunung itu\} UMOSHEH \{dan musa\} LOYADA \{tida dia mengetahui\} KI \{bahwa\} QARAN \{dia telah bersinar/ he had become radiant, Verb Qal Perfect $3^{\text {rd }}$ Mas. Sing.\} 'OR \{kulit/ skin\} PANAV \{wajahnya/ kulit mukanya\} BEDAB'RO \{karena telah berbicara dengan-Nya/ dia, Verb Piel Infinitive Construct + Suffix $3^{\text {rd }}$ Mas. Sing.\} 'ITO \{pada dia/ Dia\}

Latin Vulgate, cumque descenderet Moses de monte Sinai tenebat duas tabulas testimonii et ignorabat quod cornuta esset facies sua ex consortio sermonis Dei.

Douay-Rheims Bible, And when Moses came down from the mount Sinai, he held the two tables of the testimony, and he knew not that his face was horned from the conversation of the Lord.

Ketika Musa turun dari gunung Sinai, ia memegang dua loh kesaksian, dan ia 
tidak tahu bahwa wajahnya "bertanduk" dari percakapan dengan Tuhan (terjemahan dari Latin Vulgate). Sumbersumber Alkitab Yahudi, untuk Kel 34:29, menerjemahkan dalam bahasa Inggris kata dengan shoresh: קרן - Qof-Resh-Nun itu, sbb:

Chabad, And it came to pass when Moses descended from Mount Sinai, and the two tablets of the testimony were in Moses' hand when he descended from the mountain and Moses did not know that the skin of his face had become radiant (QARAN) while He had spoken with him.

Hebrew Names Version (HNV), It happened, when Moshe came down from Mount Sinai with the two tablets of the testimony in Moshe' hand, when he came down from the mountain, that Moshe didn't know that the skin of his face shone (QARAN) by reason of his speaking with him.

St. Jerome menerjemahkan Alkitab bahasa asli ke dalam bahasa Latin "Vulgata" pada Abad ke-4 Masehi. Dengan pemahaman bahwa kata Ibrani Rקרן - QARAN (dia telah bersinar/ he had become radiant), yang sinarnya menyerupai "tanduk-tanduk" קררנגיטם - QAR'NAYIM - yang memancarkan cahaya dan menjorok seperti bentuk tanduk. Pemahaman ini dirupakan dalam satu karya seni rupa "Musa bertanduk," diantaranya adalah karya besar "Michelangelo's Horned Moses."
Dalam kehidupan Musa, ia banyak menghadapi pandemi, penyakit sampar, yang pertama pada peristiwa tulah ke-10, MAKAT BEKHOROT.

\section{Gambar 1. Mosè di Michelangelo}

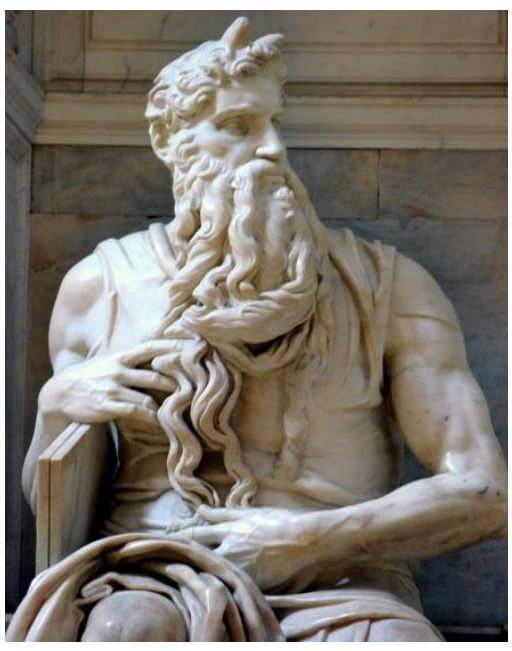

Musa mengingat peristiwa besar ini

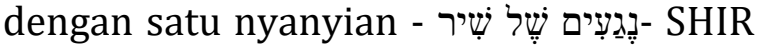
SHEL NEGA'IM (harf: nyanyian tulah, reff. Mazmur pasal 91, Talmud Shevu'ot 15b). Yang kedua adalah peristiwa pandemi yang disebabkan gigitan ular-ular tedung (Bil. 21:6-9).

\section{God - Dewa Kemakmuran}

Kata dalam bahasa Inggris "God" berhubungan dengan bahasa Ibrani: GAD -soresh: Gimel-Daled - G-D, perhatikan ayat ini:

* Yesaya 65:11

LAI TB, Tetapi kamu yang telah meninggalkan TUHAN, yang telah 
melupakan gunung-Ku yang kudus, yang menyajikan hidangan bagi dewa Gad (GAD), dan yang menyuguhkan anggur bercampur rempah bagi dewa Meni: $\mathrm{KJV}$, But ye are they that forsake the LORD, that forget my holy mountain, that prepare a table for that troop, and that furnish the drink offering unto that number.

NET Bible, But as for you who abandon the LORD and forget about worshiping at my holy mountain, who prepare a feast for the god called 'Fortune' (GAD), and fill up wine jugs for the god called 'Destiny'-

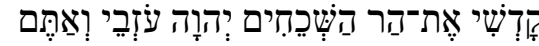

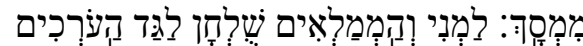

Translit interlinear, VE'ATEM \{dan kalian\} 'OZ'VEY \{orang-orang yang telah meninggalkan $\}$ YEHOVAH (dibaca: 'Adonay, TUHAN) HASHEKHEKHIM \{orang-orang yang telah melupakan\} ET\{pada\} HAR \{gunung\} KADSHI \{kudus-Ku\} HA'ORKHIM \{orang-orang yang menyediakan sesaji\} LAGAD \{pada dewa gad - G-D\} SHULKHAN \{pada meja\} VEHAM'MALIM \{orang-orang yang memenuhi suguhan (ibadah)\} LAM'NI \{pada dewa meni\} MIM'SAKH \{minuman sesaji\}

Ternyata kata "God" berasal dari nama dewa keberuntungan "fortune," dewa kemakmuran. Hal ini mungkin berasal dari satu konsep, bahwa yang disembah sebagai "God" adalah pribadi yang memberikan "fortune" keberuntungan.

Konsep beribadah untuk mencari kemakmuran, juga sangat melanda gereja-gereja secara universal pada masa kini. Mereka memperlakukan "Tuhan untuk melayani manusia." Janji-jadi berkat, bahkan klaim berkat pada "Fortune God." Tuhan yang diperlakukan seperti "jin" yang memenuhi apa saja permintaan si Alibaba. Konsep Tuhan yang melayani manusia dalam memenuhi kebutuhan hidupnya, yang memberikan kemakmuran bukah hal baru, ini adalah konsep purba paganistik. Konsep cara pandang seperti ini, ditegur keras di dalam Alkitab.

Kata Inggris "good" artinya: fortune, success, berhubungan dengan ayat ini:

*Kejadian 30:11

LAI TB, Berkatalah Lea: "Mujur telah datang." Maka ia menamai anak itu Gad. KJV, And Leah said, A troop cometh: and she called his name Gad.

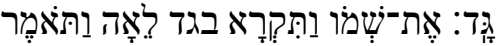

Translit interlinear, VATOMER \{dan dia berkata\} LE'AH \{lea\} BAGAD \{dalam keberuntungan\} VATIQ'RA \{maka dia memanggil\} 'ET- \{pada\} SHEMO \{namanya\} GAD \{gad/ untung/ fortune Ibrani, Aram, dan Arab yang Mempengaruhi Bahasa Indonesia.

Ada bahasa yang sama tuanya dengan bahasa Ibrani, dia adalah bahasa Aram. Kita dapat melihat buktinya di Alkitab, pada Laban - לָרָָ - LAVAN - yang masih 
kerabat dengan Abraham yang disebut orang Ibrani - הָצְבְרִרי - HA'IVRI. Bahwa

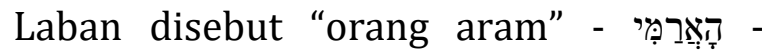
HA'ARAMI (Kej. 15:20, 18:5, 31:20, 24). Bahasa Ibrani dan Bahasa Aram adalah bahasa yang serumpun, sama-sama rumpun Semit. Digunakan oleh Bapakbapa leluhur Israel.

Sekarang pertanyaannya: manakah yang lebih dulu setelah bahasa Edenics: "Bahasa Ibrani" ataukah "Bahasa Aram"?12 Bagi orang-orang Yahudi, dengan mendasarkan pada Zefanya 3:9, tentulah bahasa Ibrani yang lebih dulu, bahasanya Ibrahim, bapak dari bangsabangsa:

* Zefanya 3:9

LAI TB, "Tetapi sesudah itu Aku akan memberikan bibir lain kepada bangsabangsa, yakni bibir yang bersih, supaya sekaliannya mereka memanggil nama TUHAN, beribadah kepada-Nya dengan bahu-membahu.

$\mathrm{KJV}$, For then will I turn to the people a pure language, that they may all call upon the name of the LORD, to serve him with one consent.

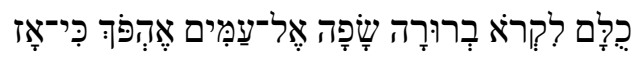

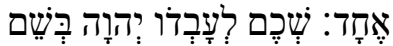

Translit interlinear, KI- \{tetapi\} 'AZ \{sesudah\} 'EH'POKH \{aku memberikan\} 'EL- \{pada\} 'AMIM \{bangsa-bangsa\}

12 Baca Raymond F. Person. "The Postmodern Bible Reader." Shofar An Interdisciplinary Journal of Jewish Studies 22, no.4 (January 2004): 155-156.
SAFAH \{bahasa\} VERURAH \{di dalam kemurnian\} LIQ'RO \{untuk memanggil\} KHULAM \{merela sekalian\} BESHEM \{di dalam Nama\} YEHOVAH (dibaca: 'Adonay, TUHAN) LE'AV'DO \{untuk beribadah kepada-Nya\} SHEKHEM 'EKHAD \{bersatu bahu-membahu\}.

Pandangan bahwa "Edenic" adalah "Semitic mother tongue" dan yang kemudian terurai menjadi 70-bahasa bangsa-bangsa dunia melalui keturunan Nuh (Kej. pasal 10), kemudian ragam bahasa ini terus berkembang. Karena bahasa Indonesia banyak sekali menyerap kata-kata Arab masuk ke dalam bahasa Indonesia. Maka ada banyak sekali katakata yang mirip dengan bahasa Ibrani. Nama-nama hari dalam Bahasa Indonesia:

1. Hari pertama, אחָָד י יוֹם YOM 'EKHAD atau hari Ahad (Minggu) disebut juga - ראשוֹן יוֹם - YOM RI'SHON;

2. Hari kedua, שִׁני יוֹם - YOM SHENI atau hari Senin;

3. Hari ketiga, שִׁלישישי יוֹם - YOM SHELISHI atau hari Selasa;

4. Hari keempat, רְבִיעִי יוֹם - YOM REVI'I atau hari Rabu;

5. Hari kelima, חִדִמישׁי יוֹם - YOM KHAMISHI atau hari Kamis;

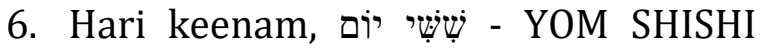
atau hari Jumat (berhubungan dengan kata "jemaat." 
7. Hari ketujuh, שְׁבִיצי יוֹם - YOM SHEVI'I

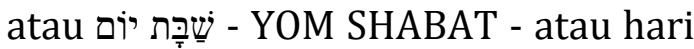
Sabtu.

Kata "SALAM" adalah kata serapan dari bahasa Arab, memiliki makna/ arti yang sama dengan bahasa Ibrani: שָׁלוֹ SHALOM. Kata "ZIKIR" adalah kata serapan dari bahasa Arab, memiliki makna/ arti yang sama dengan bahasa

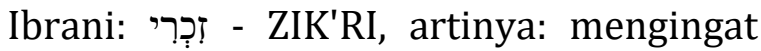
akan aku.

Kata serapan Arab "Amin" maknanya sama dengan bahasa yang serumpun dengannya, yaitu bahasa Ibrani : אָָמָן 'AMEN, Alef - Mem - Nun, Leksikon Ibrani: verily, truly, amen, so be it, pasti! sungguh! benar! jadilah demikian! Kata 'AMEN ini berjenis adverbia, menerangkan verba, yang dapat pula bermakna "begitulah hendaknya, so be it" (Yer. 11:5).

Kata serapan Arab "hikmat," adalah dalam artian seperti halnya kebajikan "intelektual Ibrani." Kata hikmat dalam bahasa Ibrani: חָָכָָָדה - "KHOKH'MAH" (nomina feminin). Selain itu masih ada kata lain, misalnya בִּיָָּ - "BINAH" (nomina feminin), pengertian (Ayub 39:20) yang diserap dalam bahasa Indonesia "bina"(dalam artian mendidik).
Anda tentu tahu kata "Kasbon." Dan, orang Yahudi itu mirip dengan orang Batak, profesi yang disukai mereka, menjadi Lawyer atau menjadi Banker. Kata "KASBON" artinya sama dengan שִ - KHES'BON, "bill". Dari kata Ibrani חשָׁׁ - KHASAV, artinya: to think/ to count. Lanjut dengan kata "Kafir," menurut Kamus Besar Bahasa Indonesia:

Kafir adalah orang yang tidak percaya kepada Allah dan rasul-Nya. Ada kafir harbi yaitu orang kafir yang mengganggu dan mengacau keselamatan Islam sehingga wajib diperangi, ada kafir muahid yaitu orang kafir yang telah mengadakan perjanjian dengan umat Islam bahwa mereka tidak akan menyerang atau bermusuhan dengan umat Islam selama perjanjian berlaku, dan ada kafir zimi yaitu orang kafir yang tunduk kepada pemerintahan Islam dengan kewajiban membayar pajak bagi yang mampu. ${ }^{13}$

Istilah "Kafir" sesungguhnya dari bahasa Ibrani juga. Bahasa Indonesia menyerapnya dari kata Arab. Dari kajian sisi homofonik, berasal dari istilah bahasa Ibrani yang diambil dari Mitsvot Hukum Taurat Nomer 341 tentang larangan terhadap segala hal yang berhubungan dengan: חָרֶר הברר - KHOVER KHAVER, $a$ caster of spells, hal-hal yang berhubungan

\footnotetext{
${ }^{13}$ Sumber: Kamus Besar Bahasa Indonesia, (C) Balai Pustaka 1997 https://kbbi.web.id/kafir
} 
dengan roh-roh dan pemanterapemantera. Berhubungan dengan verba Ibrani בָּפָ - KAFAR, artinya: smear over, to abolish, menebus. Yang kemudian kata "KAFAR" digunakan dalam maksud "eufemisme" (penghalusan bahasa) untuk menyebut kepada "orang-orang yang belum ditebus."

Meski awalnya "KHOVER KHAVER" digunakan dalam artian eufemisme, namun ratusan, bahkan ribuan tahun kemudian kata "Kafir" ini menjadi sangat menakutkan, orang dapat membunuh saudaranya dengan label "kafir," oleh karena perbedaan keyakinan (agamanya).

Istilah dalam bahasa Indonesia "Harta Karun," ternyata juga berasal dari kisah dalam Alkitab Ibrani (Bilangan 16:32). Kata "Karun" nama ini diadaptasi dari bahasa Arab: "Qarun" (QS. Al Qashash: 76-79) adalah KORAH, Ibrani: - קרח - QORAKH. Nah, KORAH QORAKH yang memberontak itu, apakah menjadi muasal dari kata "korak" (preman tukang palak) dalam bahasa prokem Indonesia? Mungkin saja iya.

\section{Kajian Kemiripan Bunyi dan Permutasi} Huruf

Pada contoh kata-kata di atas, mungkin Anda bahwa penelitian itu didasarkan pada "kemiripan bunyi" saja. Dalam diskusi saya dengan Dr. Mozeson, saya tertarik dengan penelitian beliau. Bahwa kajian origin bahasa tidak hanya didasarkan pada "kemiripan bunyi," saja, tetapi juga meneliti "permutasi" dari huruf-hurufnya.

Beliau mengajukan kata dalam bahasa Indonesia "PALSU" - P-L-S - yang berhubungan dengan kata Ibrani: פְִּ PESEL, Fe-Samekh-Lamed - P-S-L mengacu pada "patung berhala," terbuat dari kayu atau batu yg diukir. Patungpatung berhala pada allah-allah yang lain (yang palsu), reff. Yes. 40:20, 44:15, Yer 8:19; Hos. 11:2; Mik. 5:13.

\section{Edenics - Ibrani, Apakah Bahasa Sorga?}

Sejauh ini saya dapat menerima kajian dan penelitian dari Dr. Isaac E. Mozeson mengenai "Edenic Language" yang menjadi "Semitic mother tongue" dan bahkan terurai menjadi 70-bahasa bangsa-bangsa dunia, dan mempengaruhi bahasa bangsa-bangsa di dunia. Hanya 
saja... Jika ada pertanyaan, Apakah bahasa Ibrani juga merupakan "bahasa sorga"?

Sebab, ada kalangan Kristen yang "katanya mau kembali ke akar Yudaik" mereka berpendapat bahwa Bahasa Ibrani adalah bahasa Sorga, sehingga orang-orang Kristen harus memanggil Nama Tuhan dengan akar Hebraic: "Yahweh." Mereka berpendapat, di Sorga nama "Yahweh" itulah yang digunakan.

* 2 Korintus 12:2-4

12:2 LAI TB, Aku tahu tentang seorang Kristen; empat belas tahun yang lampauentah di dalam tubuh, aku tidak tahu, entah di luar tubuh, aku tidak tahu, Allah yang mengetahuinya-orang itu tiba-tiba diangkat ke tingkat yang ketiga dari surga.

KJV, I knew a man in Christ above fourteen years ago, (whether in the body, I cannot tell; or whether out of the body, I cannot tell: God knoweth; ) such an one caught up to the third heaven.

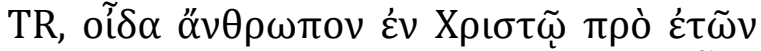

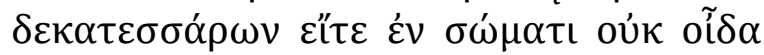

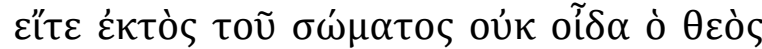

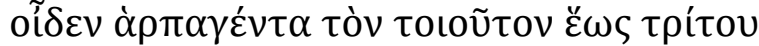
oúpavoũ

Translit interlinear, oida \{aku mengenal\} anthrôpon \{seorang\} en \{dalam\} khristô \{Kristus\} pro \{sebelum\} etôn \{tahuntahun\} dekatessarôn \{empat belas\} eite \{ataukah\} en \{dalam\} sômati \{tubuh\} ouk \{tidak\} oida \{aku tahu\} eite \{atau\} ektos \{di luar\} tou sômatos \{tubuh\} ouk \{tidak\} oida \{aku tahu\} ho theos \{Allah\} oiden $\{$ tahu\} harpagenta \{diambil dengan tibatiba\} ton \{(orang)\} toiouton \{demikian\} heôs \{ke\} tritou \{(tingkat) ke-tiga $\}$ ouranou \{surga\}

12:3 LAI TB, Aku juga tahu tentang orang itu, -- entah di dalam tubuh entah di luar tubuh, aku tidak tahu, Allah yang mengetahuinya

$\mathrm{KJV}$, And I knew such a man, (whether in the body, or out of the body, I cannot tell: God knoweth;)

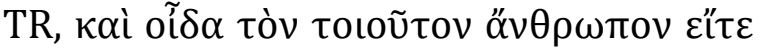

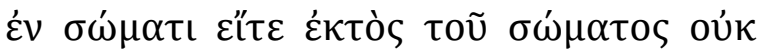
oĩ $\delta \alpha$ ò $\theta \varepsilon \hat{\varsigma} \varsigma$ oĩ $\delta \varepsilon v$

Translit interlinear, kai $\{$ lalu\} oida $\{a k u$ mengenal\} ton toiouton \{demikian\} anthrôpon \{seorang\} eite \{ataukah\} en sômati \{di dalam tubuh\} eite \{atau\} ektos tou sômatos \{di luar tubuh\} ouk oida \{aku tidak tahu ho theos $\{$ Allah\} oiden $\{$ tahu

12:4 LAI TB, ia tiba-tiba diangkat ke Firdaus dan ia mendengar kata-kata yang tak terkatakan, yang tidak boleh diucapkan manusia.

$\mathrm{KJV}$, How that he was caught up into paradise, and heard unspeakable words, which it is not lawful for a man to utter.

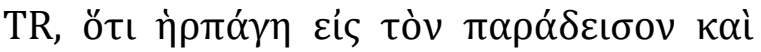

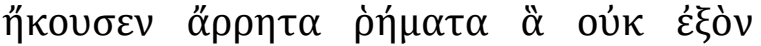
$\alpha \dot{\alpha} v \theta \rho \omega \dot{\pi} \omega \lambda \alpha \lambda \tilde{\eta} \sigma \alpha \mathrm{L}$.

Translit interlinear, hoti \{bahwa\} hêrpagê \{ia diambil dengan tiba-tiba\} eis $\{\mathrm{ke}$ dalam\} ton paradeison \{firdaus\} kai \{dan\} êkousen \{mendengar\} arrêta \{yang tak boleh dikatakan\} rêmata \{kata-kata\} ha \{yang\} ouk \{tidak\} exon \{boleh\} anthrôpô \{manusia\} lalêsai \{mengucapkan/ mengatakan\}. ${ }^{14}$

14 Pada abad ketujuh belas, pencarian bahasa yang sempurna adalah gerakan intelektual utama Eropa. Pencarian itu dimotivasi oleh berbagai keprihatinan, dari harapan/ketakutan apokaliptik hingga kebutuhan akan ketepatan 


\begin{abstract}
Perhatikan cara Rabi Saul menceritakan pengalamannya, ia tidak menggunakan kata ganti orang pertama "aku," tetapi ia menggunakan kata ganti orang ketiga yaitu "Seseorang yang aku kenal" dan "ia." Gaya bahasa demikian, selaras dengan gaya bicara semitik yang lebih banyak menghindari kata "I am
\end{abstract}

ilmiah hingga dorongan untuk stabilitas politik yang mungkin akan menyertai bahasa yang terbebas dari selip semantik. Untuk menemukan kembali atau menciptakan bahasa yang sempurna, para sarjana modern awal mencoba merekonstruksi pidato Eden atau beralih ke kode linguistik matematika abstrak. Cendekiawan modern telah membahas partisipasi Milton dalam proyek intelektual ini, mencatat ketidakhadiran yang tampaknya aneh dari keterlibatan dengan subjek yang diberikan minat intelektual Milton, lingkaran teman-temannya, dan fakta bahwa ia menulis sebuah puisi besar tentang Eden prelapsarian. Namun, diskusi tentang Milton dan bahasa yang sempurna cenderung menyatukan berbagai untaian yang berbeda dari penyelidikan intelektual ini. Gambaran yang jauh lebih halus muncul ketika kita mempertimbangkan garis pemikiran yang berbeda di dalam gerakan, model ilmiah Baconian dan pendekatan mistik yang diambil oleh para pengikut Jacob Boehme. Tidak hanya para sarjana yang menyatukan keduanya, tetapi penyelidikan untuk bahasa yang sempurna telah dianggap sebagai upaya intelektual maskulin atau netral gender. Faktanya, skema bahasa sangat bergantung pada idiom dan struktur gender. Mempertimbangkan cara-cara yang berbeda di mana pendekatan Baconian dan Boehmian untuk bahasa yang sempurna menyebarkan gender memungkinkan kita untuk melihat bagaimana untaian yang berbeda ini dimanifestasikan melalui mode penamaan masing-masing yang digunakan oleh Adam dan Hawa di Paradise Lost. Kristen Poole."Naming, Paradise Lost, and the Gendered Discourse of Perfect Language Schemes." English Literary Renaiisance, 36, Iss.3 (2008): 535-560. https://doi.org/10.1111/j.1475-

6757.2008.00135.x.
('ANI HU)" dalam setiap pembicaraan, namun hal ini juga menunjukkan bahwa Rabbi Saul adalah seorang yang rendahhati. Ia tidak mau menggunakan kata-kata Aku-nya Paulus layak diangkat ke Firdaus, sebaliknya ia mengungkapkannya dengan bahasa sopan-santunnya seorang Yahudi yang telah mempunyai pengalaman spiritual yang luar biasa.

Di dalam pengelihatannya itu, Rabbi Saul mendengar "kata-kata yang tak terkatakan, yang tidak boleh diucapkan manusia," jika kata-kata itu adalah bahasa Ibrani, tentulah Rabbi Saul tahu dan dapat mengerti. Apabila kata-kata itu adalah bahasa Aram, tentulah juga Rabbi Saul tahu artinya dan dapat mengerti. Tetapi ia menyatakan "kata-kata yang tak terkatakan, yang tidak boleh diucapkan manusia." Tentulah bahasa di Sorga itu sama sekali lain dengan bahasa-bahasa di dunia ini. Berdasarkan 2 Kor.12:2-4, saya dapat memastikan bahwa apapun bahasa di dunia ini, bukan bahasa kekekalan. Bahasa Ibrani bukan bahasa Sorga (Bahasa Ibrani bukan bahasa yang digunakan di Sorga). Bahkan "Bahasa Lidah"-pun dikatakan akan berlalu (1 Kor. 13:8). Lantas, akan memakai bahasa apakah kita nanti? 
Ketika berada di langit baru dan bumi yang baru, kita akan sama-sama tahu dan bersama-sama menggunakannya.

*Wahyu 21:1-2

21:1 LAI TB, Lalu aku melihat langit yang baru dan bumi yang baru, sebab langit yang pertama dan bumi yang pertama telah berlalu, dan lautpun tidak ada lagi.

$\mathrm{KJV}$, And I saw a new heaven and a new earth: for the first heaven and the first earth were passed away; and there was no more sea.

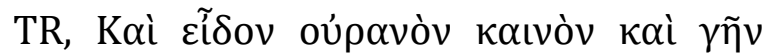

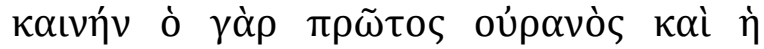

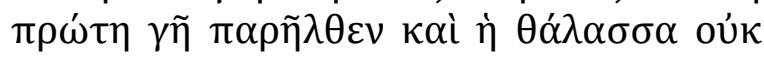

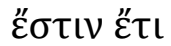

Translit interlinear, kai \{dan\} eidon \{aku melihat\} ouranon \{lagit\} kainon \{baru\} kai \{dan\} gên \{bumi\} kainên \{baru\} ho gar \{sebab\} prôtos \{yang pertama\} ouranos \{langit\} kai \{dan\} hê \{yang\} prôtê \{pertama\} gê \{bumi\} parêlthen \{telah berlalu\} kai \{dan\} hê thalassa \{laut\} ouk \{tidak\} estin $\{$ ada $\}$ eti $\{$ lagi $\}$

OJB, And I saw Shomayim Chadashim (New Heavens) and Eretz Chadasha (a New Earth), for the shomayim harishonah (the first heaven) and haaretz harishonah (the first earth) were passed away, and there is no longer any Yam (Sea).

Haberit hakhadashah,

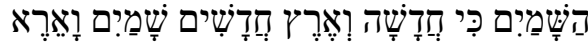

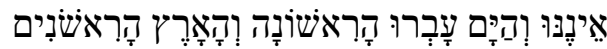

עוֹד:

Translit interlinear, VA'ERE \{dan aku melihat\} SHAMAYIM \{langit\} KHADASIM \{yang baru\} VE'ERETS \{dan bumi\} KHADASHAH \{yang baru\} KI $\{$ sebab HASHAMAYIM \{langit\} HARISHONIM \{yang pertama\} VEHA'ARETS \{dan bumi\}
HARISHONAH \{pertama yang \} 'AVERU \{mereka telah berlalu\} VEHAYAM \{dan laut\} 'EINENU \{tidak ada\} 'OD \{lagi $\}$

21:2 LAI TB, Dan aku melihat kota yang kudus, Yerusalem yang baru, turun dari sorga, dari Allah, yang berhias bagaikan pengantin perempuan yang berdandan untuk suaminya.

$\mathrm{KJV}$, And I John saw the holy city, new Jerusalem, coming down from God out of heaven, prepared as a bride adorned for her husband.

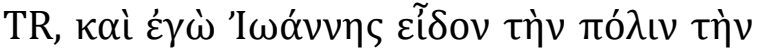

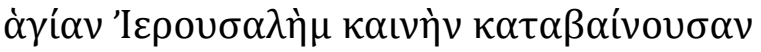

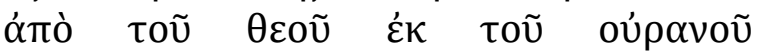

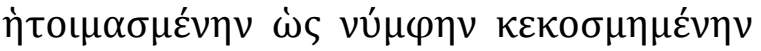
$\tau \tilde{\omega} \alpha \dot{\alpha} v \delta \rho \grave{i} \alpha u ́ \tau \tilde{\eta} S$

Translit interlinear, kai \{maka\} egô \{aku\} iôannês \{yohanes\} eidon \{aku melihat\} tên polin \{kota\} tên hagian \{suci\} ierousalêm \{yerusalem\} kainên $\{$ baru katabainousan \{turun\} apo \{dari\} tou theou $\{$ Allah\} ek $\{$ dari\} tou ouranou \{surya $\}$ êtoimasmenên $\{y g$ telah disiapkan\} hôs \{seperti\} numphên \{mempelai perempuan\} kekosmêmenên \{yang didandani\} tô andri \{untuk suami\} autês $\{$-nya $\}$

OJB, And I saw the Ir Hakodesh, the Yerushalayim HaChadasha coming down and descending out of Shomayim from Hashem, having been made ready as a Kallah adorned for her Ba'al (Husband). [NECHEMYAH 11:18; YESHAYAH 52:1]

Haberit hakhadashah,

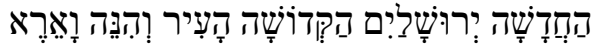

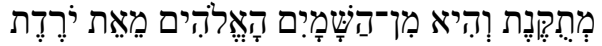

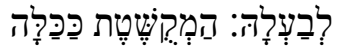

Translit interlinear, VA'ERE \{dan aku melihat VEHINEH \{bahwa ada\} HA'IR 
\{kota\} HAQEDOSHAH \{yang kudus\} YERUSHALAYIM HAKHADASHAH \{Yerusalem baru\} YOREDET \{Dia menurunkan\} ME'ET HA'ELOHIM \{dari Allah\} MIN-HASHAMAYIM \{dari Sorga VEHI \{dan dia\} METUQENET \{yang dia telah dipersiapkann\} KAKALAH \{seperti mempelai perempuan\} HAMEQUSHETET \{dia berdandan\} LEVA'ELAH \{bagi suaminya

\section{KESIMPULAN}

Isaac E. Mozeson, seorang liguist di Israel ia meneliti bahwa bahasa Ibrani yang mempengaruhi banyak bahasabahasa di dunia. Dia menyebut "Edenics" adalah "proto-human language" ini karena hubungannya dengan Taman Eden, dimana manusia pertama diciptakan dan ditempatkan di situ. Maka "Edenics" adalah mula dari bahasa Ibrani Alkitabiah. Menurut teorinya, setiap bahasa manusia saat ini memiliki unsurunsur bahasa Ibrani. Edenics adalah bahasa pra-Yahudi.

Salah satu contoh dari hipotesis Mozeson itu adalah dengan mengambil contoh kata yang kata paling mudah. Satu kata yang terdapat benar-benar terdapat di dalam Taman Eden, yaitu kata: 'ADAM, artinya: manusia yang terhubung erat dengan kata artinya: tanah. Tanah adalah satu media dari mana 'ADAM itu dibentuk/ diciptakan. Kata 'ADAM dikenal di seluruh dunia dalam artian yang sama. Dengan demikian, "Edenic Language" menjadi "Semitic mother tongue" dan bahkan terurai menjadi 70-bahasa bangsa-bangsa dunia, dan mempengaruhi bahasa bangsabangsa di dunia.

\section{KEPUSTAKAAN}

Adler, Rivkah Lambert. Reff. https://www.breakingisraelnews.co m/ 138823/biblical-hebrew-motherlanguages-before-after-tower-babel/ (diakses 10 Feb. 2021).

Bodie Hodge. Tower of Babel, The Cultural History of Our Ancestors. Green

Forest: Master Books, 2013.

Elder Conrad Jarrell. The Story in The

Stars. Morrisville: Lulu, 2018.

Isaac E. Mozeson. The Word: The

Dictionary Reveals the Hebrew Sounce of English. New York: S.P.I. Books, 2001. Edenics DVD on Edenic (Biblical Hebrew) as the original, pre-Babel human language program. http://www.edenics.org/ Kementerian Pendidikan. Kamus Besar Bahasa Indonesia. Jakarta: Balai 
Pustaka, 1997.

https://kbbi.web.id/kafir

Loy, Eric C. "Savage Garden: Edenic Motif and the Paradox of Civilization in Child of God." The Cormac McCarthy Journal 12 (2014): 55-68. http://www.jstor.org/stable/10.532 5/cormmccaj.12.55.

Person, Raymond F. "The Postmodern Bible Reader." Shofar An Interdisciplinary Journal of Jewish Studies 22, no.4 (January 2004): 155156.
Poole, Kristen."Naming, Paradise Lost, and the Gendered Discourse of Perfect Language Schemes." English Literary Renaiisance, 36, Iss.3 (2008): 535-560. https://doi.org/10.1111/j.14756757.2008.00135.x

Santoso, Agus. Dabar. Tata Bahasa Ibrani. Bandung : Bina Media Informasi, 2011.

Wahyu, Rita. Eksegesis Peshat Kitab Kejadian-Kitab Genealogi, Parashat Bereshit 1:1-6:8. Jakarta: STT Ekumene, 2019. 